\title{
Repair Performance Landslide and Slope Using Bore pile and Ground Anchor on Cipali Toll Road Km 103
}

\author{
A. Akhmudiyanto ${ }^{1 *}$, P. P. Rahardjo ${ }^{2}$, R. Karlinasari ${ }^{3}$. \\ ${ }^{1 * 2,3}$ Civil Engineering Postgraduate Parahyangan University, Bandung. \\ Email: ${ }^{*}$ Akhmudiyanto123@gmail.com.
}

\begin{tabular}{l}
\hline ARTICLE INFO \\
\hline Article History: \\
Article entry $: 22-02-2021$ \\
Article revised $: 03-10-2021$ \\
Article received $: 26-11-2021$ \\
\hline
\end{tabular}

Keywords :

Borepile, Cipali Toll Road, Ground Anchor, Landslides, Slope repair.

IEEE Style in citing this article: [1] K. Trgala, M. Pavelek, and R. Wimmer, "Energy performance of five different building envelope structures using a modified Guarded Hot Box apparatusComparative analysis," Energy Build., 2019, doi: 10.1016/j.enbuild.2019.04.036

\begin{abstract}
One of the causes of on-road collapse slopes is traffic load. Slope failure by road loads usually occurs due to several factors such as soil type, rainfall, land use. This study aims to determine landslide and slope repair performance using bore pile and ground anchor on Cipali Toll Road KM 103. The research method used in this study is the Finite element method. In this research, data collection, modeling parameter determination, slope stability analysis, slope reinforcement analysis, and reinforcement design were carried out with variations in bore pile and ground anchor dimensions. The software program used is a finite element program in the form of PLAXIS to analyze slope stability and estimate the slope failure area. The result of the study is that the R-Value inter is 0.25 with a 1.0341 safety factor. Best repair performance obtained from the addition of reinforcement with ground anchor 2 layer on bore pile 2 with a distance of 2 meters increased the safety factor to 1,913; Borepile capacity calculation with the calculation of normal force and moment iteration, the largest occurs in the DPT (Retaining Wall) stage with a normal load of -37.9 and a moment force of -471.15 which is still able to be borne by bore pile 1. The result of this study is expected to be benchmark and repair material to improve slope stability at $\mathrm{km} 103$ Tol Cipali.
\end{abstract}

\section{Introduction}

The massive infrastructure development carried out by the government has changed the natural structure. Infrastructure works include roads, bridges, dams, airports, residential docks, and basement excavations for buildings, all of these infrastructure works undergo excavation and stockpiling phases [1]. As a result of this work, the land will be found sloping due to differences in height. Differences in length can cause a problem tendency. Therefore it is necessary to calculate or analyze the stability of the slope against the forces involved [2].

Slope stability analysis plays a very important role in civil construction planning. The 
initial condition of the soil is not always by the desired plan. For example, because the slope is too high, it is necessary to reduce the slope or reduce the height of the land that needs to be stockpiled [3]. Stability is essential in digging and storing soil, rocks, and minerals because it includes human (worker) safety, equipment safety, and even production issues.[4] The difficulty level of sloping land causes soil erosion which in terms of erosion control makes it different from the difficulty of flat land. The intensity of high rainfall can be predicted to cause steepness on the slopes[5]. The excavation and fill construction work that is carried out must follow the technical requirements by the SNI geotechnical to avoid landslides. Slope stability analysis is a crucial element in reducing lethal disasters and regular production disruptions [6].

The Cipali toll road itself is a toll road that has a quite crucial role where it functions as a distribution route for goods and services across Java to Sumatra [7]. The situation is nonsplitting (natural), and the rocks are generally balanced in an upward force. Non-destructive (natural) vertical, horizontal and high pressure is applied to soil and rocks [8]. All three play an important role in slope stability. One of the earth construction works is an effort to increase directional stability in various ways, such as geometric changes of slopes, monitoring of groundwater, and installing anchors [9]. A bored pile is a foundation with concrete elements with holes inserted through the holes in the drill. While Ground Anchor is a system for distributing tensile forces acting on bore pile polishes to soil layers or even supporting rocks. Research conducted by Winarto (2019) shows that strengthening the ground anchor is considered more effective in stopping the slope movement in Cisomang. Installation of the ground anchor can be said that the slope is declared stable. However, at KM 103 CikopoPalimanan Toll Road (Cipali) has not been improved with the optimal use of bore pile and ground anchor.

A landslide occurred at KM 103 Tol Cikopo-Palimanan (Cipali) in the direction of Jakarta due to the Cibening River. The landslide occurred on the shoulder of the road with a length of about 30 meters and a depth of about 1 to 2 meters, located at KM 103, which includes the Subang area. Precautions have been taken by installing piles in areas affected by landslides. However, the installed pile creates instability during soil collection, which causes fragmentation of the pile. Some of the reviews that are done include reviewing images that come from design and implementation [8]. The sample is taken as a test on the results of construction and inspection of facilities and traffic management[11]. Therefore, re-analysis is carried out to determine a more precise slope reinforcement. The bore pile structure and ground anchor need to be done modeling parameter determination, slope stability analysis, slope reinforcement 
analysis, and reinforcement design. So that with the re-analysis and the known strengthening of slope more precisely, it can be used as a reference in the repair of landslides and slopes KM 103 Cikopo-Palimanan Toll Road (Cipali).

\section{Theoritical Review}

\subsection{Slope Stability}

Analysis of the stability of the slope is always related to the development of soil mechanics and rock usage in general [12]. The most common problems with long-term stability are soil stability and low soil bearing capacity. Reliable analysis of maintenance and reinforcement downtime is required to reach the best solution for the above problems. Overall, the main objective of slope stability analysis is to develop a safe and cost-effective construction plan[13]. The causes of slope failure should start by considering the fundamental requirements for slope stability, where the shear strength in the soil must be of a value greater than that required for equilibrium [14]. Some of the main factors causing slope failure are described as follows:

\section{a. Increased Pore Pressure}

A rise in water level in the soil and deteriorating seepage conditions result from heavy rainwater, which causes an increase in pore pressure and a decrease in effective pressure on the associated slopes where all soil types are affected.[15].

\section{b. Increased Shear Stress}

The increase in shear stress is the resistance force done by the grains of soil against collapses and shifts that occur due to the burden he was experiencing. In particular, in geotechnical fields for soil strength is usually shown in the shear strength [16].

\section{c. Increase the load above the slope}

If the soil at the top of the slope is loaded, the shear stress required for slope balance will increase.

\section{d. Water pressure in cracks on top of slopes}

If there is a crack at the top of the slope that is sliced with water (or partially filled), the hydrostatic pressure of the water in the gap in the soil in the slope will increase with increasing shear stress.[17]. If the crack remains filled with water for long enough, the slope will deteriorate. 


\section{$2.2 \quad$ Types of Slope Landslide}

The shape of the slip plane that is common and often encountered is the shape gel plane that approximates the shape of a circular arc. Earthquake damage can consist of various mechanisms and triggers [18]. These can be classified based on the type of landslide, type of material, development or age of the soil. The types of landslides can be divided into translational landslides and rotational landslides [19].

\subsection{Bored Pile}

It is a foundation with concrete elements with holes inserted through the holes in the drill. Heavy loads on the soil will be placed on slopes with stronger soil or rock components through the concrete foundation [20]. The drilling process is carried out with low-frequency vibrations to carry out the construction process[17]. Other ways that can be used to strengthen the foundation include protecting the building to stabilize the slope.

\subsection{Ground Anchor}

Ground Anchor is a system for distributing tensile forces acting on bore pile polishes to soil layers or even supporting rocks [21]. This anchoring system consists of a fixed length, free length, and anchor head component. The anchoring system can be broken into a temporary ground anchor with a service life of $\leq 2$ years and a permanent ground anchor with a service life of> 2 years [22].

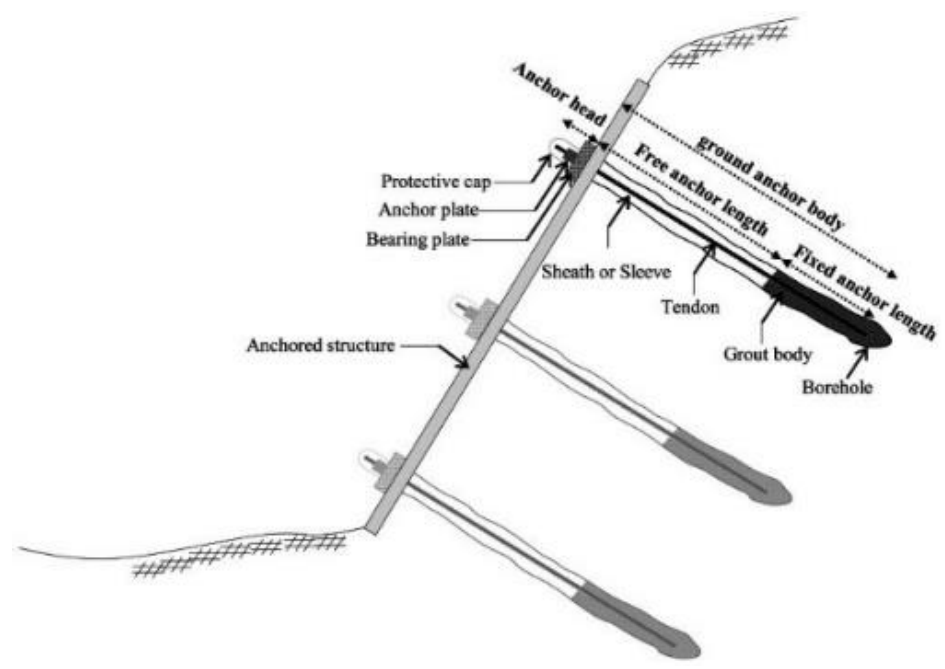

Sources : Grant Surya Multi Sarana (2020)

Figure 1. Ground Anchor 


\section{Research Method}

This study is a recalculation of the landslides that occurred at the Cipali Toll Road at KM 103. Landslide repair has been carried out by installing $50 \mathrm{~cm}$ diameter piles. Within a few months, it turned out that these piles were not able to withstand the continuous landslide loads due to truck and car loads as well as due to heavy rain, so that the piles with bored piles had a larger diameter with the aim of being able to withstand the Landslide force [23].

1. Data Collection

The data collected in this study is secondary data obtained from geotechnical consultants PT. GEC includes 2-point drill data and 3 DCPT (Sondir). Drilling is placed on the road body and on-road slopes where landslides have occurred.

2. Determination of Modeling Parameters

At this stage, the Standard Penetration Test (SPT) is carried out. Soil parameter correlation from DCPT (Sondir) data and soil parameter correlation based on laboratory results.

3. Slope Stability Analysis Method

The method used in the analysis of slope stability with circle collapse. In slope stability analysis using finite element method to count and analyze the soil and slope reinforcement. To prevent landslides for all types of soil can be done in several ways [24]. Stability analysis is carried out by taking into account the slope geometry model and the correlation of soil parameters as well as soil data in the form of borehole data, cone penetration test data $(\mathrm{CPT})$, and cone penetration test with pore pressure $(\mathrm{CPTu})$

4. Slope Reinforcement Analysis

Slope reinforcement analysis includes slope stability analysis, bore pile detection analysis, and ground anchor capacity analysis.

5. Reinforcement Design

At the reinforcement design stage, the bored pile and Ground Anchor design will be carried out.

This bore pile pole is placed at 2 locations, the first location in the middle of the landslide field and the second on the shoulder of the road. This is done to allow the planted pole to stick firmly and not move or break [25]. The poles installed on the shoulder of the road will experience direct pressure from the shoulder of the road, consisting of asphalt material that is expected to minimize landslides in the future. The second row of the bore pile or on the road's shoulder will be reinforced with earth retaining wall whose construction is on top of bore pile poles. This retaining wall (DPT) functions to hold soil particles from breaking through the bore 
pile when the bottom of the slope is a landslide [26] [27]. There was a collapse after the local area was showered with high rainfall for 4 consecutive days.

\section{Geotechnical Condition}

Meanwhile, the geotechnical condition is defined as a description of the soil condition in the area around the study obtained from the investigation results [28]. The purpose of finding out the geotechnical conditions is to facilitate the supporting elements for implementing the next stage that must be carried out. Field and laboratory test results yield plant data.

Geotechnical conditions on the output slopes can be seen from boring logs and CPT (sondir) tests [29]. The result of boring long produce soil data with $2 \log$ drill points and 3 sondir points, related to stability analysis and slope improvement, the focus is given covering 2 drill points as well as 1,2 and 3 sondir points, the data is taken on the shoulder of the road in the middle of the plane landslides and in the leg of the landslide field. Boring log data at points $\mathrm{BH}-\mathrm{A}$ and $\mathrm{BH}-\mathrm{B}$ is shown in the following.

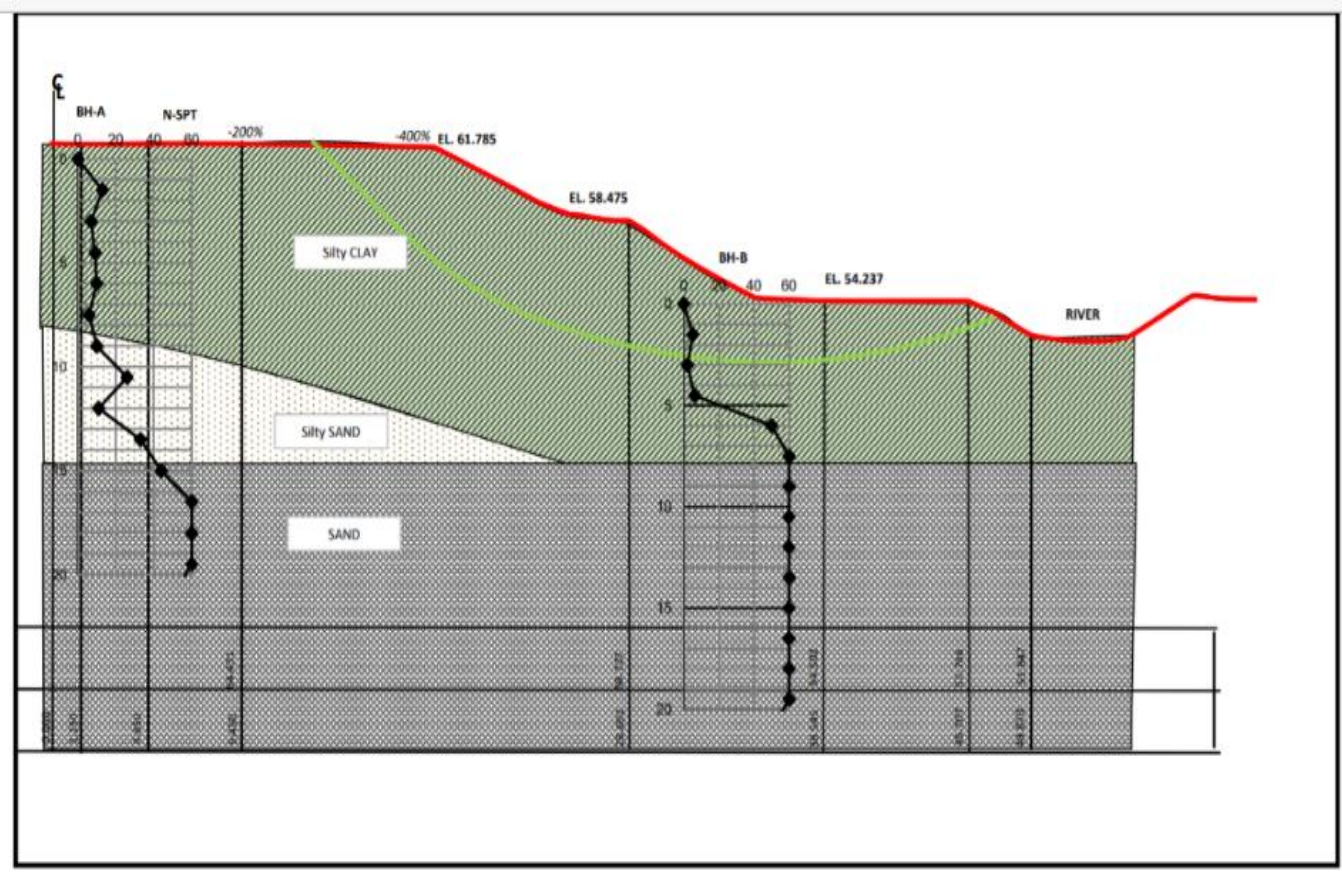

Sources : GEC(2020)

Figure 2. Longitudinal section of the soil layer in the BH-A and BH-B borlogs

Soil data obtained at the landslide location based on bore log data at $\mathrm{BH}-\mathrm{A}$ is divided into 3 layers with varying depths for each layer, namely: The top layer is silty clay with a depth of 0-8 $\mathrm{m}$, the next layer on the road is a layer of silty sand depth of 8-13 m, the next layer is a layer of sand depth to 13-20 end of drilling. In the case of landslides on the Cipali toll road km 103, analyzing soil stability is the reinforcement method with a bore pile structure and ground anchor. In slope stability analysis using Finite element method. Slope stability analysis begins 
by knowing how the conditions of slope stability and reinforcement have been carried out, the condition of the Cibening river flow. The next stage is the evaluation of traffic diversion, placement of work tools, and evaluation of data resulting from land investigations [30].

After the visual observation is done, the next analysis is the slope stability analysis method to find out the value of the safety factor on the slope and an estimate of the slope failure area. The software program used is a finite element program in the form of PLAXIS. The slope protection or strengthening system, the observation system on slope conditions, the management results that are thought to cause problems, and several other recommendations that are deemed necessary can be used as a reference for the analysis results. Some of the steps that can be taken in slope stability analysis include Qualification of the design, review of stability and deformation, results of structural strengthening studies.

\section{Result and Discussion}

\subsection{Slope Stability Analysis Method}

In determining the $\mathrm{R}$ interface, using the Back Analysis method is one of the calculation methods to find the value of the soil parameter when the slope reaches its critical value, that is when the safety factor gets 1.0. The parameters used for the Plaxis program are Mohr Coulomb's design type. The results of the calculation of slopes using this method, the $\mathrm{R}$ interface value is $=0.250$ with a safety factor of 1.0647 . From this analysis, it has been obtained that the safety factor that meets the requirements to determine the value of shear strength and residual phi angle, from the back analysis calculation results obtained a safety factor of 1.0341 .

The value of the safety factor or safety factor will produce analysis results in the form of slope reinforcement and slope reinforcement methods if using a 2-row bore pile and ground anchor2 layer, it meets the SF> 1.5 requirements. In general, the safety element of a slope compares to the value of the average displacement stability of soil and rock along the failure area, which is considered critical to the load obtained by the slope along the collapsed area. Some essential things that must be considered when determining criteria for safety factors are the amount of risk to be obtained, the conditions at the load and the high parameters used when carrying out the analysis related to slope stability.

\subsection{Slope Reinforcement Analysis}

Slope reinforcement has been carried out using dia $500 \mathrm{~mm}$ piles with a distance between the piles of approximately $1.5 \mathrm{~m}$ at the location midway through the landslide field. 


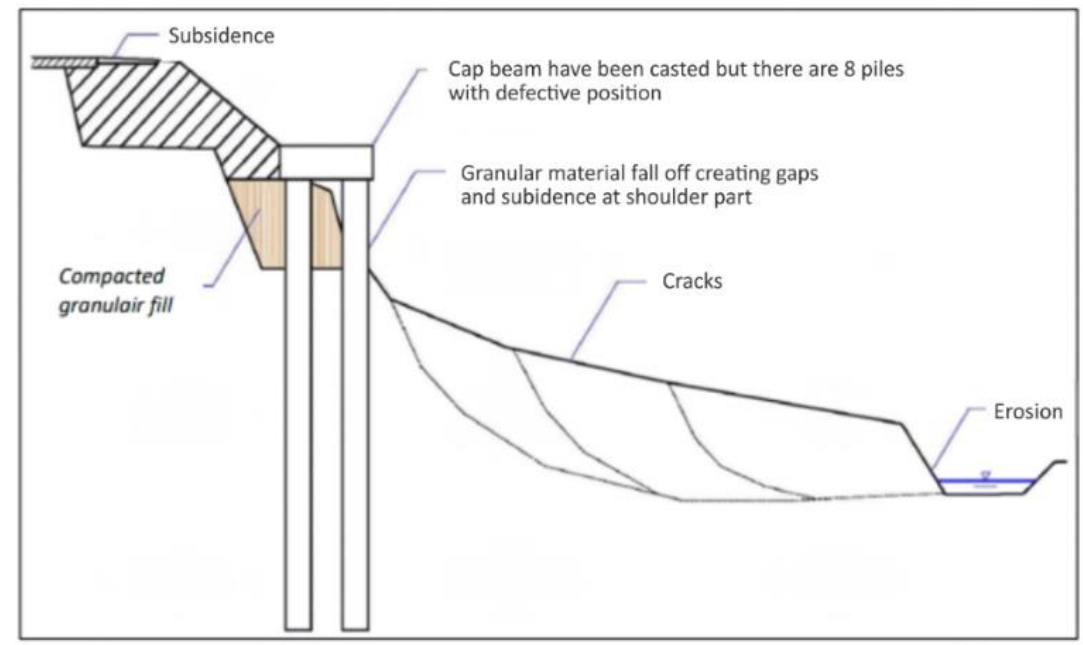

Sources : GEC (2020)

Figure 3. Soldier Pile Position

This soldier pile pole is tied using a capping beam. A few days after the soldier pile work was finished, cracks arose on the shoulder of the road as shown in Figure 3. This means there is movement on the shoulder of the road. This movement indicates that the pile is unable to withstand horizontal forces. So, it is necessary to make temporary strengthening. A sheet pile is installed temporarily on the shoulder of the road. The installation is intended to reduce the soil load behind the soldier pile.

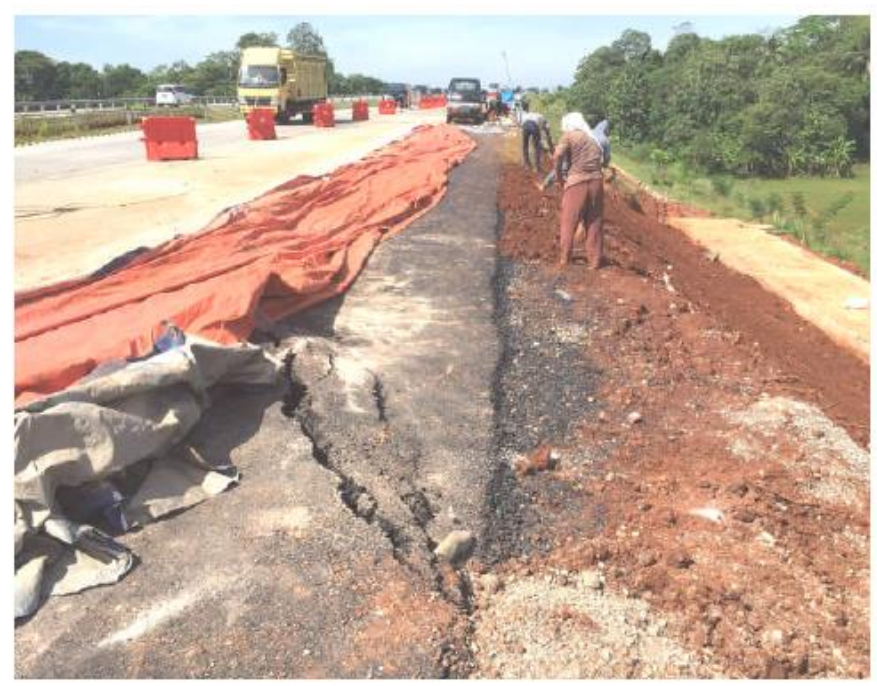

Sources : GEC (2020)

Figure 4. Crack Position

From the above incident that the soldier using a diameter 50 stake is not able to withstand landslides. It is necessary to make a design that can withstand landslides. A stronger design using a bore pile with a diameter of $880 \mathrm{~mm}$ is installed in 2 rows, namely the shoulder of the road and the middle of the landslide area. The design plan is as shown in Figure 5. 


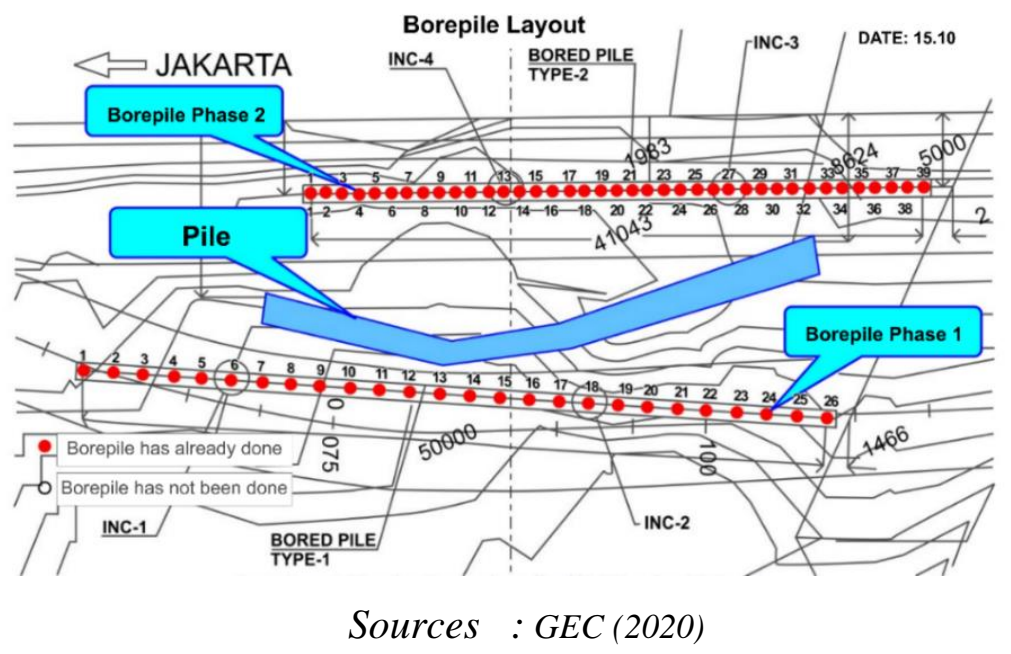

Figure 5. Slope Reinforcement Plan with 2 Borepile Lines

From the slope reinforcement plan, a calculation analysis is carried out with a $2 \mathrm{D}$ plaxis. The soldier pile pole is tied using a caping beam. Construction with these piles failed, so it needed to be redesigned. To prevent this from happening again, it is planned to have a bore pile and anchor structure with a borepile dimension of 880 with two rows in the middle of the landslide field. Below the shoulder of the landslide plane, the bore pile under the road's shoulder will be installed, a 2-layer ground anchor. Additional reinforcement was done by adding mini piles and gabions and embankments behind the gabions to reduce the angle of inclination of the soil under the shoulder of the road. The reinforcement parameters are shown in table 1.

Table 1. Reinforcement Parameters Added To The Landslide Area

\begin{tabular}{|c|c|c|c|c|c|c|c|c|}
\hline No & Description & Borepile 1 & Borepile 2 & $\begin{array}{l}\text { Retaining } \\
\text { wall }\end{array}$ & $\begin{array}{l}\text { Mini } \\
\text { stake }\end{array}$ & Gabions & $\begin{array}{l}\text { Ground } \\
\text { Anchor }\end{array}$ & Geogrid \\
\hline 1 & Diameter (mm) & 880 & 880 & 0,69 & 0,20 & & & 0,2 \\
\hline 2 & Space $(\mathrm{m})$ & 1,0 & 2,0 & 1 & 3 & & 2 & 2 \\
\hline 3 & Area (A) $\mathrm{m}^{2}$ & 0,785 & 0,785 & 0,69 & 0,04 & & 0,0314 & $\begin{array}{l}0,000633 \\
0\end{array}$ \\
\hline 4 & $\begin{array}{l}\text { Concrete quality } \\
\text { fc, }\end{array}$ & 33 & 33 & 33 & 37 & & & 33 \\
\hline 5 & $\begin{array}{l}\text { Modulus Elt } \mathrm{E} \\
\mathrm{kN} / \mathrm{m}^{2}\end{array}$ & $\begin{array}{l}26,999,00 \\
0\end{array}$ & $26,999,000$ & $\begin{array}{l}26,999,00 \\
0\end{array}$ & $\begin{array}{l}28.588 .98 \\
3,8\end{array}$ & $\begin{array}{l}2,100,00 \\
0\end{array}$ & $\begin{array}{l}195,000,0 \\
00\end{array}$ & $\begin{array}{l}195,000,0 \\
00\end{array}$ \\
\hline 6 & $\gamma_{\text {Soil }}\left(\mathrm{kN} / \mathrm{m}^{3}\right)$ & 16,5 & 16,5 & 16,5 & 16,5 & 16,5 & 16,5 & \\
\hline 7 & $\gamma_{\text {concrete }}\left(\mathrm{kN} / \mathrm{m}^{3}\right)$ & 24 & 24 & 24 & 24 & 25 & 24 & \\
\hline 8 & Type Material & Elastic & Elastic & Elastic & Elatic & & & Elastic \\
\hline 9 & Inersia $\left(m^{4}\right)$ & 0,04908 & 0,04908 & 0.0273 & 0.003255 & & & \\
\hline 10 & $\mathrm{EA}(\mathrm{kN} / \mathrm{m})$ & $5,806 \mathrm{E} 06$ & $9,676 \mathrm{E} 06$ & $1,158 \mathrm{E} 06$ & $1,158,565$ & & & $7,723,770$ \\
\hline 11 & $\mathrm{EI}\left(\mathrm{kN} / \mathrm{m}^{2} / \mathrm{m}\right)$ & $2,810 \mathrm{E} 5$ & $4,683 \mathrm{E} 05$ & 736,118 & 6,034 & & & \\
\hline 12 & $\mathrm{~d}(\mathrm{~m})$ & 0,762 & 0,762 & 0,69 & 0,25 & & & \\
\hline 13 & w kN/m & 2,073 & 3,455 & 5,520 & 0,333 & & & \\
\hline 14 & Poisson's number & 0,15 & 0,15 & 0,15 & 0,15 & 0,2 & & \\
\hline 15 & Bore length (m) & 14 & 20 & & 6 & & & \\
\hline
\end{tabular}

Source : Author's Calculation Data (2020)

Repair Performance Landslide and Slope Using Bore pile and Ground Anchor on Cipali Toll Road Km 103 http://dx.doi.org/10.30737/ukarst.v3i2 
Borepile capacity to the ability of concrete and steel materials is calculated using the PCA column program. The data inputted for bore pile calculations are as follows:

Table 2. Input data for the PCA COLUMN program

\begin{tabular}{|c|c|c|c|}
\hline No. & Description & Score & Unit \\
\hline 1 & Borepile diameter & 880 & $\mathrm{~mm}$ \\
\hline 2 & Borepile iron diameter & $16 \mathrm{D} 32$ & \\
\hline 3 & Concrete strength fc ' & 33 & Mpa \\
\hline 4 & Elasticity of concrete Ec & 26,999 & $\mathrm{Mpa}$ \\
\hline 5 & Pull the iron Fy & 390 & Mpa \\
\hline 6 & Elasticity steel Ice & 200000 & Mpa \\
\hline
\end{tabular}

Sources : Author's Calculation Data (2020)

The results of the largest normal force iteration calculation at the DPT work stage the force borne by bore pile 1 is the normal force $-37.9 \mathrm{kN}$, and the moment bore pile $\mathrm{Bp} 1$ at this stage is $-471.15 \mathrm{kNm}$, resulting in an iteration of the force still in the area of the iteration capacity of the bore pile 1 . So that bore pile 1 can withstand the greatest moment and normal loads in all stages of the analysis.

\subsection{Reinforcement Design}

Due to the embankment behind the wall, the safety factor decreases. It is necessary to increase the ground anchor. This ground anchor is placed on the pile placed on the head of the pile, or capping beam. The force arising from the addition of a ground anchor causes additional safety factors, reducing deflection in the bore pile.

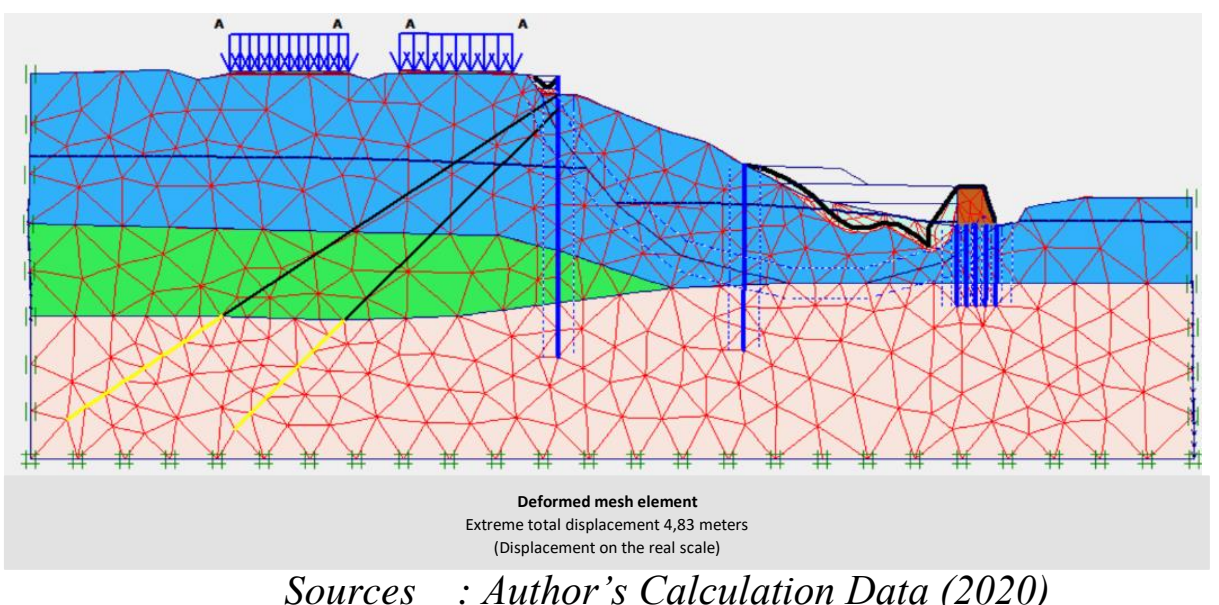

Figure 6. Reinforcement of Slopes with Ground Anchor

Figure 6 shows that the addition of this ground anchor causes a change in the force on the borpile, retaining wall, and mini piles. Slope reinforcement with 2 bore pile piles and ground anchor resulted in a safety factor of 1.913. the slope with the safety factor is considered safe Repair Performance Landslide and Slope Using Bore pile and Ground Anchor on Cipali Toll Road Km 103 
$(\mathrm{SF} \geq 1.5)$. The outputs reviewed are the magnitude of the axial force, extreme, extreme shear force, extreme bending moment force, and horizontal deformation acting on bore piles BP2, retaining walls, and Mini Piles.

Figure 7 becomes a presentation in the slope stability obtained conditions after the calculation process has ended. The addition of this ground anchor causes changes in the force on the Borpile, soil retaining wall, and mini stakes. The changes are shown below.

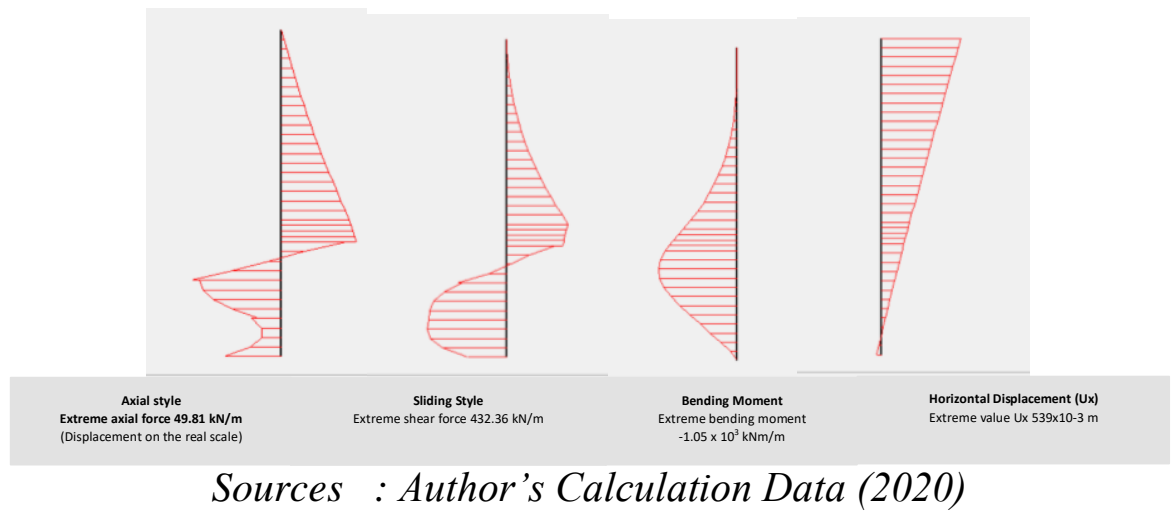

Figure 7. Force on BP1 due to strengthening of the ground anchor.

In calculating the tensile capacity of the ground anchor, it is different from calculating the moment capacity and normal force on the bore pile. The moment capacity in the bore pile is determined by the concrete's quality and the amount of reinforcement used. Concrete and iron are homogeneous materials, and quality can be controlled so that the moment capacity, normal force, and shear capacity can be calculated with certainty. While the tensile capacity of the ground anchor is determined by the friction resistance between the soil and the grout in the bond length section. The plaxis (Figures in below) calculation results obtained the total ground anchor tensile force : 1) Layer $1=501,8 \mathrm{kN}<898,0 \mathrm{kN} \ldots$ (save) \& 2) Layer $2=333,47$ $\mathrm{kN}<805,4 \mathrm{kN}$.... Save

The next step is to compare the results of the analysis to the inclinometer measurements. Inclino meters for the landslide project on the Cipali 103 toll road were installed at 4 locations. The first and second on the phase 1 bore pile, namely inclino 1 and inclino 2 , while the Inclino 3 and Inclino 4 are placed on the phase 2 bore pile. The locations of the inclinometer readings and Plaxis calculations are presented in the following figure: 


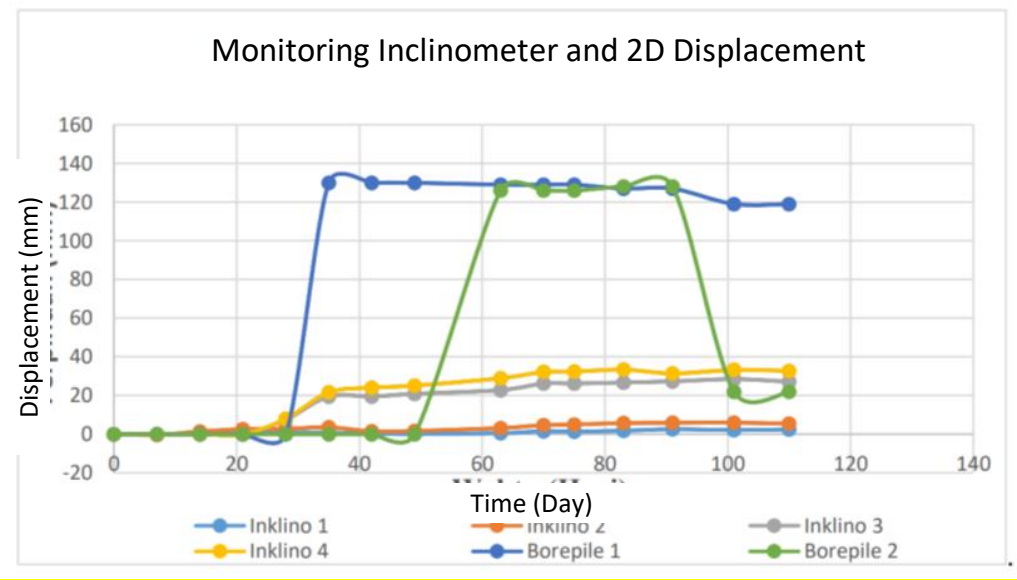

Sources : Author's Calculation Data (2020)

Figure 8. Monitoring Inclinometer and 2D displacement

From the image of the inclino, the actual field measurements on the BP1 bore pile (Borepile phase 1) have a maximum displacement of $5.41 \mathrm{~mm}$. the results of calculations with Plaxis 8.6 on bore pile BP1 of a maximum of $130 \mathrm{~mm}$, after being pulled with the ground anchor the displacement is $119 \mathrm{~mm}$. This value is still more significant than the actual field on borepile1. In actual field measurements on bore pile 2 the results of the inclinometer displacement are $33.23 \mathrm{~mm}$. From the results of calculations with Plaxis 8.6 the displacement value is $128 \mathrm{~mm}$ after the ground anchor is pulled, the displacement becomes $47.3 \mathrm{~mm}$. the displacement value with this Plaxis calculation is still more significant than the actual measurement results in the field.

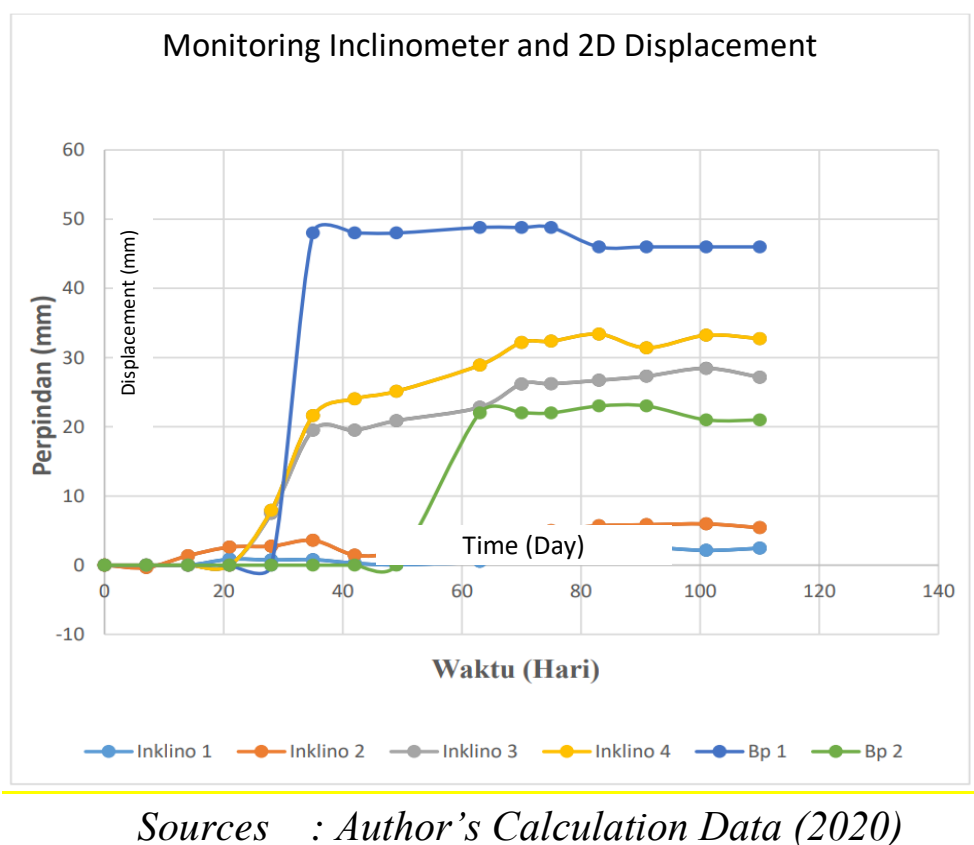

Figure 9. Monitoring Inclinometer and 3D displacement 
From the image of the actual inclino field measurements on the BP1 bore pile (Borepile phase 1), the maximum displacement is $5.96 \mathrm{~mm}$. the results of calculations with Plaxis 3D on bore pile BP1 of a maximum of $48 \mathrm{~mm}$, after being pulled with the ground anchor the displacement is $46 \mathrm{~mm}$. This value is still more significant than the actual field on borepile1. In actual field measurements on bore pile 2 the result of the inclinometer displacement is 33.39 $\mathrm{mm}$. From the results of calculations with Plaxis 3D, the displacement value is $23 \mathrm{~mm}$ after the ground anchor is pulled. The displacement becomes $21 \mathrm{~mm}$. The displacement value with this Plaxis calculation is still more significant than the actual measurement results in the field. Compared with measures with Plaxis 2D, estimates with Plaxis 3D are close to the actual results in the area.

\section{Conclusion and Suggestion}

\subsection{Conclusion}

The results of the analysis and discussion carried out on the planning to improve slope stability at km 103 Tol Cipali, the following conclusions can be drawn:

1. The slope stability results show that the $\mathrm{R}$ interface value is $=0.250$ with a safety factor of 1.0647. From this analysis, it has been obtained that the safety factor that meets the requirements to determine the value of shear strength and residual phi angle, from the back analysis calculation results obtained a safety factor of 1.0341 . The value of the safety factor or safety factor will produce analysis results in the form of slope reinforcement and slope reinforcement methods if using a 2-row bore pile and ground anchor2 layer, it meets the $\mathrm{SF}>1.5$ requirements.

2. The slope reinforcement analysis shows that the result of the Interface calculation is that the value of $\mathrm{R}$ inter: 0.25 with a safety factor of 1.0341 .

3. Based on the results of the reinforcement design, it shows that safety highest obtained from the addition of reinforcement with ground anchor 2 layer on bore pile 2 with a distance of 2 meters increased the safety factor to 1,913 ; 


\section{References}

[1] K. Trgala, M. Pavelek, and R. Wimmer, "Energy performance of five different building envelope structures using a modified Guarded Hot Box apparatus-Comparative analysis," Energy Build., 2019, doi: 10.1016/j.enbuild.2019.04.036.

[2] D. P. Wulandari, "PERENCANAAN PONDASI TIANG BOR (BORE PILE) PADA PROYEK PEMBANGUNAN GEDUNG RAWAT INAP RSUD dr. M. YUNUS KOTA BENGKULU," University of Muhammadiyah Malang, 2019.

[3] Y. A. N. Wei-dong, "Application of Drilling (Wash) Bore Pile and Rotary Jet Grouting Pile Technology to Support Project of Pumping Station Deep Pit [J]," China Water \& Wastewater, vol. 16, 2008.

[4] Y. Sheng, Z. Miao, J. Zhang, X. Lin, and H. Ma, "Energy consumption model and energy benchmarks of five-star hotels in China," Energy Build., 2018, doi: 10.1016/j.enbuild.2018.01.031.

[5] H. Wahyudiono and S. Anam, "PERENCANAAN PONDASI BORE PILE PADA PROYEK JEMBATAN NGUJANG II KAB.TULUNGAGUNG,” UKaRsT, 2018, doi: 10.30737/ukarst.v2i1.356.

[6] C. Sembiring, "Analisis Perbandingan Biaya dan Waktu Pelaksanaan Pondasi Spun Pile dengan Bore Pile pada Proyek Masjid Agung," Universitas Medan Area.

[7] P. Deye, N., Vincent, F., Michel, P., Ehrmann, S., Da Silva, D. et al., "Understanding knowledge and attitudes about breast cancer and its treatment in Ethiopia," Ann. Glob. Heal., 2015.

[8] Z. Guo, W. Li, S. Yin, D. Yang, and Z. Ma, “An innovative technology for monitoring the distribution of abutment stress in longwall mining," Energies, 2021, doi: 10.3390/en14020475.

[9] P. Paduloh and H. Hardi Purba, "Analysis of Productivity Based on Kpi Case Study Automotive Paint Industry," J. Eng. Manag. Ind. Syst., vol. 8, no. 1, pp. 1-12, 2020, doi: 10.21776/ub.jemis.2020.008.01.1.

[10] N. G. Winarto, "ANALYSIS OF GROUND ANCHOR UTILIZATION ON CISOMANG BRIDGE REVITALIZATION PROJECT,” no. April, pp. 73-78, 2019.

[11] R. H. Karsaman, “Audit Keselamatan Jalan Tol di Indonesia (Studi Kasus Jalan Tol Cikampek - Padalarang/Cipularang),” J. Tek. Sipil ITB, vol. 14, no. 3, 2007. 
[12] C. Becchio, D. G. Ferrando, E. Fregonara, N. Milani, C. Quercia, and V. Serra, "The cost-optimal methodology for the energy retrofit of an ex-industrial building located in Northern Italy," Energy Build., 2016, doi: 10.1016/j.enbuild.2016.05.093.

[13] S. Adi, I. Saputra, and Y. M. H. Adha, "Analisis Stabilitas Lereng Dengan Perkuatan Dinding Penahan Tanah Kantilever Dan Geotekstil Pada Ruas Jalan Lintas Liwa Simpang Gunung Kemala KM. 268+550,”J. Ilm. Fak. Tek. Univ. Lampung, 2017.

[14] D. Kolokotsa et al., "Development of a web based energy management system for University Campuses: The CAMP-IT platform," Energy Build., 2016, doi: 10.1016/j.enbuild.2016.04.038.

[15] V. M. Nik, E. Mata, A. Sasic Kalagasidis, and J. L. Scartezzini, "Effective and robust energy retrofitting measures for future climatic conditions - Reduced heating demand of Swedish households,” Energy Build., 2016, doi: 10.1016/j.enbuild.2016.03.044.

[16] L. Sun, S. Chandra, and P. Sucosky, "Ex Vivo Evidence for the Contribution of Hemodynamic Shear Stress Abnormalities to the Early Pathogenesis of Calcific Bicuspid Aortic Valve Disease," PLoS One, 2012, doi: 10.1371/journal.pone.0048843.

[17] A. Saptowati, H., Wahono, T., \& Bagas, "Influence of blankets bore pile on soil characteristics irradiator gamma merah putih of serpong," J. Phys. Conf. Ser., vol. 1436, no. 1, p. 012043, 2020.

[18] Z. Yang, S. Zhou, J. Zu, and D. Inman, "High-Performance Piezoelectric Energy Harvesters and Their Applications," Joule. 2018, doi: 10.1016/j.joule.2018.03.011.

[19] A. M. Youssef, H. R. Pourghasemi, Z. S. Pourtaghi, and M. M. Al-Katheeri, "Landslide susceptibility mapping using random forest, boosted regression tree, classification and regression tree, and general linear models and comparison of their performance at Wadi Tayyah Basin, Asir Region, Saudi Arabia,” Landslides, 2016, doi: 10.1007/s10346-0150614-1.

[20] F. Tan, Y. Y. Jiao, H. Wang, Y. Liu, H. nan Tian, and Y. Cheng, "Reclamation and reuse of abandoned quarry: A case study of Ice World \& Water Park in Changsha," Tunn. Undergr. Sp. Technol., 2019, doi: 10.1016/j.tust.2018.12.009.

[21] R. J. Jardine, "Geotechnics, energy and climate change: The 56th Rankine Lecture," Geotechnique, 2020, doi: 10.1680/jgeot.18.RL.001.

[22] Y. Wang, X. Sun, and A. Ren, "Investigations of rock anchor corrosion and its influence factors by exhumations in four typical field sites," Eng. Fail. Anal., 2019, doi: 10.1016/j.engfailanal.2019.03.022. 
[23] D. C. Denkenberger and R. W. Blair, "Interventions that may prevent or mollify supervolcanic eruptions," Futures, 2018, doi: 10.1016/j.futures.2018.01.002.

[24] S. P. Pradhan and T. Siddique, "Stability assessment of landslide-prone road cut rock slopes in Himalayan terrain: A finite element method based approach," J. Rock Mech. Geotech. Eng., 2020, doi: 10.1016/j.jrmge.2018.12.018.

[25] M. Eid, A. Hefny, T. Sorour, and Y. Zagh, "Full-Scale Well Instrumented Large Diameter Bored Pile Load Test in Multi Layered Soil: A Case Study of Damietta Port New Grain Silos Project," Int. J. Curr. Eng. Technol., 2018, doi: 10.14741/ijcet.v8i01.10895.

[26] M. G. Winter et al., "Design and construction considerations," in Geological Society Engineering Geology Special Publication, 2017.

[27] H. Suprayitno and R. A. Aryani Soemitro, "Preliminary Reflexion on Basic Principle of Infrastructure Asset Management," J. Manejemen Aset Infrastruktur Fasilitas, 2018, doi: 10.12962/j26151847.v2i1.3763.

[28] B. Pasierb, M. Grodecki, and R. Gwóźdź, "Geophysical and geotechnical approach to a landslide stability assessment: a case study," Acta Geophys., 2019, doi: 10.1007/s11600019-00338-7.

[29] R. Shirani Faradonbeh, A. Taheri, L. Ribeiro e Sousa, and M. Karakus, "Rockburst assessment in deep geotechnical conditions using true-triaxial tests and data-driven approaches,” Int. J. Rock Mech. Min. Sci., 2020, doi: 10.1016/j.ijrmms.2020.104279.

[30] E. A. Chiaradia, C. Vergani, and G. B. Bischetti, "Evaluation of the effects of three European forest types on slope stability by field and probabilistic analyses and their implications for forest management," For. Ecol. Manage., 2016, doi: 10.1016/j.foreco.2016.03.050. 